\title{
In vivo demonstration of Pseudomonas aeruginosa biofilms as independent pharmacological microcompartments
}

Christophersen, Lars; Schwartz, Franziska Angelika; Lerche, Christian Johann; Svanekjær, Trine; Kragh, Kasper Nørskov; Laulund, Anne Sofie; Thomsen, Kim; Henneberg, Kaj-Åge; Sams, Thomas; Høiby, Niels Total number of authors:

11

Published in:

Journal of Cystic Fibrosis

Link to article, DOI:

10.1016/j.jcf.2020.01.009

Publication date:

2020

Document Version

Peer reviewed version

Link back to DTU Orbit

Citation (APA):

Christophersen。 L., Schwartz, F. A., Lerche, C. J., Svanekjær, T., Kragh, K. N., Laulund, A. S., Thomsen, K., Henneberg, K-A., Sams, T., Høiby, N., \& Moser, C. (2020). In vivo demonstration of Pseudomonas aeruginosa biofilms as independent pharmacological microcompartments. Journal of Cystic Fibrosis, 19(6), 996-1003. https://doi.org/10.1016/j.jcf.2020.01.009

\section{General rights}

Copyright and moral rights for the publications made accessible in the public portal are retained by the authors and/or other copyright owners and it is a condition of accessing publications that users recognise and abide by the legal requirements associated with these rights.

- Users may download and print one copy of any publication from the public portal for the purpose of private study or research.

- You may not further distribute the material or use it for any profit-making activity or commercial gain

- You may freely distribute the URL identifying the publication in the public portal 
Accepted for publication in Journal of Cystic Fibrosis, 2020, Elsevier, BY-NC-ND 4.0 http://creativecommons.org/licenses/by-nc-nd/4.0/

\section{IN VIVO DEMONSTRATION OF PSEUDOMONAS AERUGINOSA BIOFILMS AS INDEPENDENT PHARMACOLOGICAL MICROCOMPARTMENTS}

Lars Christophersen $^{\mathrm{a}}$, Franziska Angelika Schwartz ${ }^{\mathrm{a}}$, Christian Johann Lerche ${ }^{\mathrm{a}}$, Trine Svanekjær ${ }^{\mathrm{b}}$, Kasper Nørskov Kragh ${ }^{\mathrm{c}}$, Anne Sofie Laulund ${ }^{\mathrm{a}}$, Kim Thomsen ${ }^{\mathrm{a}}$, Kaj-Åge Henneberg ${ }^{\mathrm{b}}$, Thomas Sams $^{\mathrm{b}}$, Niels Høiby ${ }^{\mathrm{a}, \mathrm{c}}$, Claus Moser ${ }^{\mathrm{a},{ }^{*} \text {. }}$

${ }^{\mathrm{a}}$ Department of Clinical Microbiology, Rigshospitalet, Copenhagen University Hospital. Henrik Harpestrengsvej 4A, 2100-DK, Copenhagen, Denmark.

${ }^{b}$ Department of Health Technology, Technical University of Denmark. Ørsteds Plads 349, 2800DK, Kgs. Lyngby, Denmark.

${ }^{\mathrm{c}}$ Institute for Immunology and Microbiology and the Costerton Biofilm Center, Faculty of Health and Medical Sciences, University of Copenhagen, Panum Institute, Blegdamsvej 3B, 2200-DK, Copenhagen, Denmark.

Running title: Biofilms as pharmacological compartments

*Corresponding author: Claus Moser, Department of Clinical Microbiology, Copenhagen University Hospital Rigshospitalet, Henrik Harpestrengsvej 4A, 2100-DK, Denmark, Tel: +45 3545 6400, Fax: +45 3545 6412, email address: moser@dadlnet.dk 


\begin{abstract}
Background: Pseudomonas aeruginosa is difficult to eradicate from the lungs of cystic fibrosis (CF) patients due to biofilm formation. Organs and blood are independent pharmacokinetic (PK) compartments. Previously, we showed in vitro biofilms behave as independent compartments impacting the pharmacodynamics. The present study investigated this phenomenon in vivo.
\end{abstract}

Methods: Seaweed alginate beads with $P$. aeruginosa resembling biofilms, either freshly produced (D0) or incubated for 5 days (D5) were installed s.c in BALB/c mice. Mice ( $n=64)$ received tobramycin $40 \mathrm{mg} / \mathrm{kg}$ s.c. and were sacrificed at $0.5,3,6,8,16$ or $24 \mathrm{~h}$ after treatment. Untreated controls $(n=14)$ were sacrificed, correspondingly. Tobramycin concentrations were determined in serum, muscle tissue, lung tissue and beads. Quantitative bacteriology was determined.

Results: The tobramycin peak concentrations in serum was $58.3( \pm 9.2) \mathrm{mg} / \mathrm{L}$, in lungs $7.1 \mathrm{mg} / \mathrm{L}$ $( \pm 2.3)$, muscle tissue $2.8 \mathrm{mg} / \mathrm{L}( \pm 0.5)$ all after $0.5 \mathrm{~h}$ and in D0 beads $19.8 \mathrm{mg} / \mathrm{L}( \pm 3.5)$ and in D5 beads $24.8 \mathrm{mg} / \mathrm{L}( \pm 4.1)$ (both $3 \mathrm{~h})$. A 1-log killing of $P$. aeruginosa in beads was obtained at $8 \mathrm{~h}$, after which the bacterial level remained stable at $16 \mathrm{~h}$ and even increased in D0 beads at $24 \mathrm{~h}$. Using the established diffusion retardation model the free tobramycin concentration inside the beads showed a delayed buildup of $3 \mathrm{~h}$ but remained lower than the MIC throughout the $24 \mathrm{~h}$.

Conclusions: The present in vivo study based on tobramycin exposure supports that biofilms behave as independent pharmacological microcompartments. The study indicates, reducing the biofilm matrix would increase free tobramycin concentrations and improve therapeutic effects.

Keyword: alginate beads; chronic infection; biofilm model; independent pharmacological compartment; pharmacodynamics; pharmacokinetics

Abbreviations: CFU, colony forming units; LB, lysogeny-broth; MIC, minimum inhibitory concentration; PBS, phosphate-buffered saline; PD, pharmacodynamic; PK, pharmacokinetic; PMN, polymorphonuclear neutrophils; RPM, rounds per minute.

\title{
1.Introduction
}

Substantial improvements in diagnostics and treatments have been obtained for patients with cystic fibrosis $(\mathrm{CF})$, resulting in a tremendously improved prognosis for the patients [1]. However, chronic lung infections remain the major cause for premature death in CF patients [1], especially with 
Pseudomonas aeruginosa. It is generally accepted that biofilm formation in the lungs of patients with $\mathrm{CF}$ or chronic lung disease (e.g. bronchiectasis) provides the mechanism leading to the persistent airway infections, since biofilm growth renders the bacteria tolerant to the host response and to antibiotics [2]. Biofilm formation has also been revealed for emerging CF pathogens like Achromobacter xylosoxidans, Burkholderia multivorans, Stenothrophomonas maltophilia and even for Mycobacterium abscessus [2].

Biofilms are defined as bacteria living as microcolonies embedded in a self-produced matrix consisting of exopolysaccharides, extracellular bacterial DNA (eDNA), proteins and host components [3]. The tolerance of biofilms to antibiotics, characterized by in vitro susceptibility by standard antibiotic susceptibility testing, but in vivo resistance, has several contributing and overlapping explanations. Gradients of nutrients and oxygen from the surface or exterior to the center of the biofilms, are considered important for the tolerance [3,4]. The resulting tolerance is explained by slow bacterial growth, a reduced oxygen dependent antibiotic effect, upregulation of $\beta$-lactamases and chelation of antibiotics by eDNA as the most important factors [5-8]. Important for the gradients is of course also the biofilm matrix. Since the matrix is embedded in, although distinct from, the surrounding tissue, we suggested that biofilms and the polymeric matrix could be regarded as an independent pharmacokinetic (PK) microcompartment with exclusive antibacterial behavior [9]. Blood is considered the first compartment and any organs including muscles, lungs, interstitial tissue or brain the second compartment. In previous in vitro studies we showed that biofilms behave and can be regarded as independent PK microcompartments with impact on the pharmacodynamics (PD). By using our biofilm model of seaweed alginate beads with embedded $P$. aeruginosa we developed a model system which for the first time was able to investigate the PK and PD in a biofilm simultaneously [10]. In contrast to what was expected, tobramycin accumulated inside the biofilm matrix at almost 7 times the surrounding $40 \mathrm{mg} / \mathrm{L}$ concentration [10]. Our subsequent detailed PK study confirmed this [6]. Further we found that the total concentration of tobramycin in the alginate beads follows a power law with power 0.76 as a function of the free concentration [6]. This leads to a factor 15 more bound tobramycin than free at free concentration of $1 \mathrm{mg} / \mathrm{L}$. The tobramycin-binding to the alginate matrix takes place throughout the volume of the beads and leads to a retardation of changes in the local concentration of tobramycin of a factor 12 at free concentration $1 \mathrm{mg} / \mathrm{L}$. The data-based PK model confirmed that the biofilm behaves as an independent microcompartment which contributes substantially to the biofilm antibiotic tolerance [11]. In the current article, we combine the tobramycin-alginate-bead model with a reaction- 
diffusion model describing the growth of the bacteria while taking into account oxygen availability [14]. The aim of the modeling is to test whether the protection of the bacteria against the antibiotic treatment accounts for the observed PK/PD of the antibiotic tolerance when taking into account the known important factors: retardation of tobramycin penetration into the alginate biofilm and availability of oxygen stimulating growth of the bacteria.

However, those studies were all performed in vitro with PK simulation, and it remained to be clarified how the biofilms behave in vivo during a simultaneously measurement of the PK inside the biofilm matrix and the PD by means of bacterial killing. In addition, those studies were performed with fresh beads with presumable minor eDNA. Several in vivo biofilm models have been established, including our seaweed alginate chronic lung infection model, mimicking bacterial biofilm behavior [12,13]. We, therefore, decided to use a modification of this $P$. aeruginosa alginate bead model to study the PK/PD of biofilms in vivo with freshly made beads as well as older beads which had incubated for 5 days. Using enlarged beads allowed for recovery of the beads at various time points up to $24 \mathrm{~h}$ and thereby to relate the PK and PD in vivo. In addition to the performed measurements, a tobramycin killing model was established integrating the diffusionretardation description for tobramycin in the alginate beads with an antibiotic killing model [14].

\section{Material and methods}

\section{Bacterial strain}

The wild type P. aeruginosa PAO1 Iglewski strain was used in the present study. Bacteria were grown in lysogeny-broth (LB) (Panum Institute, Copenhagen, Denmark) at $37^{\circ} \mathrm{C}$ for $18 \mathrm{~h}$ reaching an optical density (OD) of 1.7. The $5 \mathrm{~mL}$ overnight culture was centrifuged at $4400 \mathrm{~g}$ and resuspended in $2.5 \mathrm{~mL} \mathrm{LB}$. The MIC of tobramycin for the PAO1 strain (planktonic growth) was determined to be $1.5 \mathrm{mg} / \mathrm{L}$ by E-test (bioMérieux, Durham, Britain).

\section{Bead preparation}

Seaweed alginate beads with and without $P$. aeruginosa were prepared using droplet generation by gravity method described previously with minor modifications [10,12]. Protanal LF 10/60 (IMCD, Helsingør, Denmark) was dissolved in $0.9 \% \mathrm{NaCl}$ to an alginate concentration of $3 \%$ and sterilized by heating $\left(95^{\circ} \mathrm{C}\right.$ for $15 \mathrm{~min}$ ). The bacteria culture was diluted 1:20 in alginate. Then transferred to 
a 20-mL syringe and placed in a syringe pump (Graseby 3100; Ardus Medical Inc., Watford, UK). The alginate was extruded though a plastic tube at a constant flow rate of $40 \mathrm{~mL} / \mathrm{h}$ resulting in droplets falling into a gelling bath containing $0.1 \mathrm{M}$ Tris $-\mathrm{HCL}$ and $12.5 \mathrm{mM} \mathrm{CaCl}_{2}$. The tip of the plastic tube was fixed $8 \mathrm{~cm}$ above the surface of the gelling solution and a magnetic stirrer (VWR lab disc, Rødovre, Denmark) was placed underneath the gelling bath to keep the beads separated during gelling. The beads were in the gelling bath for $1 \mathrm{~h}$ to stabilize and washed twice in $0.9 \%$ $\mathrm{NaCl}$ containing $0.1 \mathrm{M} \mathrm{CaCl}_{2}$. The beads measured $2.3 \mathrm{~mm}$ in diameter and the weight was $50 \mathrm{mg}$ each. After washing, the beads were kept in $0.9 \% \mathrm{NaCl}$ containing $\mathrm{CaCl}_{2}$ to maintain stability. In addition, D5 beads were prepared by incubating the beads at $37^{\circ} \mathrm{C}$ and in $\mathrm{LB}$ medium during light shaking 150 RPM changing the medium every day. D5 bead were produced 5 days prior to the experiment to be ready simultaneously with the D0 beads.

\section{Confocal laser scanning microscopy of P. aeruginosa in alginate beads}

D0 and D5 seaweed alginate beads were exposed to propidium iodine to reveal eDNA. Beads grown for either 0 or 5 days where halved using sterile razor blade. The halved beads were placed with the profile, specifically the cut surface, downward on a \#1.5 of coverglass (Mariefeld, Germany). Beads were covered with $200 \mu \mathrm{l}$ of a $3 \mu \mathrm{M}$ Syto9 (Life Technologies, USA) and $20 \mu \mathrm{M}$ propidium iodine (PI) (Sigma-Aldrich, USA) saline solution for $15 \mathrm{~min}$ at RT in the dark. Viability and eDNA content were evaluated using a Zeiss LSM 880 inverted confocal microscope running Zen 2.1 (Zeiss, Germany). Images were obtained with a 63x/1.5 oil immersion objective with Airy scan detection using track separated $488 \mathrm{~nm}$ and $561 \mathrm{~nm}$ lasers. Emission was restricted with a 495$550 \mathrm{~nm}$ band pass and $570 \mathrm{~nm}$ long pass filter. Image was setup in Imaris 9.1 (Bitplane, Switzerland).

\section{Quantitation of P. aeruginosa in alginate beads}

To determine the number of entrapped bacteria in the alginate, the beads, either from bead preparation or in beads recovered from the sacrificed mice, were homogenized in $0.1 \mathrm{M}$ citric acid buffer $\mathrm{pH} 7$ to release the bacteria. Serial 10-fold dilutions were made and cultured on a modified Conradi-Drigalski medium (Statens Serum Institute (SSI), Copenhagen, Denmark), selective for 
Gram-negative rods. The number of colony-forming units (CFU) was determined after overnight incubation at $37^{\circ} \mathrm{C}$.

\section{Mouse strain}

Seventy-eight female, 10-week-old BALB/c mice (Janvier Labs, Le Genest-Saint-Isle, France) were used for this study. Animals were left to acclimatize for at least one week before the experiment. Animals had free access to chow and water.

\section{Challenge procedure}

The study design was based on a previous pilot study involving 24 mice. To simulate a biofilm infection, three D0 seaweed alginate beads embedded with $P$. aeruginosa PA01 were installed s.c. in BALB/c mice $(\mathrm{n}=48)$. In a follow up experiment, three D0 and three D5 seaweed alginate beads embedded with $P$. aeruginosa PA01 were installed s.c in BALB/c mice $(n=30)$. The treated mice $(n=64)$ received one dose of tobramycin $40 \mathrm{mg} / \mathrm{kg}$ s.c. to resemble human PK and were sacrificed at $0.5,3,6,8,16$ or $24 \mathrm{~h}$ after treatment. A control group of untreated, but infected mice $(n=14)$ was sacrificed at $0.5,6,16$ and $24 \mathrm{~h}$. In treated mice the tobramycin concentration was determined in serum, quadriceps femoris muscle, lungs and alginate beads. Quantitative bacteriology was determined in all the beads, which were retrieved upon sacrifice.

\section{Determining the Tobramycin concentration}

The total concentration of tobramycin in serum, quadriceps femoris muscle, lungs and alginate beads was measured using Thermo Scientific Indiko (Clinical Diagnostics, Thermo Fisher Scientific, Allerød, Denmark). The lower limit of Quantitation (LLOQ) of the tobramycin assay is defined as the lowest concentration of an analyte that can be reliably detected and at which the total error meets accuracy requirements. The LLOQ for clinical use is set to be $0.4 \mu \mathrm{g} / \mathrm{mL}$ by the manufacturer, however, values are provided below $0.4 \mathrm{mg} / \mathrm{mL}$ and used in the present study, since deviation from tested values between 0 and $0.5 \mu \mathrm{g} / \mathrm{mL}$ is $20 \%$ or lower in most cases, there is no observed variation and no false positives (quadruplicates, own data). Therefore, range of the tobramycin assay is 0 to $10.0 \mu \mathrm{g} / \mathrm{mL}$. Samples with a higher concentration than $10.0 \mu \mathrm{g} / \mathrm{mL}$ were diluted accordingly and remeasured. 
Mice were euthanized at the predefined timepoints by intraperitoneal injection of a pentobarbiturate with lidocainhydrochloride overdose (200 mg/mL and $20 \mathrm{mg} / \mathrm{mL}$, respectively). Serum was collected from the thoracic cavity after exsanguination into microcontaniers (Becton Dickinson Microtainer cat.no 365968), centrifuged at 12,000 rpm for $10 \mathrm{~min}$. Muscle tissue (300 mg) was harvested and homogenized (Heidolph Sielent Crusher M, Schwabach Germany) in $2 \mathrm{ml} 0.9 \%$ $\mathrm{NaCl}$ for $20-30 \mathrm{~s}$ at $14,000 \mathrm{rpm}$. Both kidneys $(600 \mathrm{mg})$ were harvested in $5 \mathrm{~mL} 0.9 \% \mathrm{NaCl}$ and homogenized. Lungs were harvested in $1.5 \mathrm{~mL} 0.9 \% \mathrm{NaCl}$ and homogenized. The $3 \mathrm{D} 0$ alginate beads were recovered from the subcutaneous installation from each mouse ( $n=5$ - 13/timepoint). Accordingly, the 3 D5 alginate beads were recovered ( $n=5 /$ timepoint). The 3 D0 beads per mouse were pooled and dissolved in $1 \mathrm{~mL}$ citric acid buffer, $\mathrm{pH} 7$, and homogenized. Subsequently 0.85 mL PBS was added to stabilize the solution. The 3 D5 beads per mouse were handled identically. All homogenates were centrifuged at $5000 \mathrm{rpm}$ for $15 \mathrm{~min}$ and the supernatants were sterile filtered $(0.22 \mu \mathrm{m})$ and frozen for later analysis of tobramycin concentrations.

\section{Tobramycin killing model for P. aeruginosa in alginate beads}

Modelling is essential to be able to predict antibiotic concentrations in clinical situations. Our tobramycin killing model combines the diffusion-retardation description for tobramycin in the alginate beads by Cao et al. [10] with the antibiotic killing model by Gade et al.[14]. It consists of a reaction-diffusion model for oxygen, a reaction-diffusion model for tobramycin, and a growth/killing model for the bacteria. A list of parameters used in the model is given in Table 1 .

The reaction-diffusion equation for oxygen;

$$
\frac{\partial c}{\partial t}=D_{\mathrm{O}_{2}} \frac{1}{r^{2}} \frac{\partial}{\partial r}\left(r^{2} \frac{\partial c}{\partial r}\right)-R_{\max } \frac{c}{K_{M}+c} \frac{\varepsilon}{\varepsilon_{\max }}
$$

describes the oxygen diffusion into beads and the consumption of oxygen by bacteria. Here $c$ is the oxygen concentration, $D_{\mathrm{O}_{2}}$ is the oxygen diffusion constant, $R_{\max }$ is the maximum reaction velocity, $K_{M}$ is the oxygen concentration for half-maximum reaction velocity, $\varepsilon$ is the bacterial concentration, and $\varepsilon_{\max }$ is the maximal bacterial concentration. Eq. 1 is solved with time-invariant boundary condition $c=55 \mu M$ at the tissue-bead interface [15]. 
Cao and coworkers established that, in the alginate bead model, a power-law describes well the experimental data on the total concentration of tobramycin, $a_{t}$, as a function of the free concentration, $a,[10]$. This is written;

$$
a_{t}=\alpha a^{\beta}
$$

where $\alpha$ is $16 \mathrm{mg} / \mathrm{L}, \beta$ is $0.76, a$ is the concentration of free tobramycin $(\mathrm{mg} / \mathrm{L})$. This leads to the local equilibrium condition;

$$
\frac{\partial a_{t}}{\partial t}=\alpha \beta a^{\beta-1} \frac{\partial a}{\partial t}
$$

The prefactor to the time derivative, $\alpha \beta a^{\beta-1}$, is the retardation factor. Cao et al. therefore obtained the reaction-diffusion equation;

$$
\alpha \beta a^{\beta-1} \frac{\partial a}{\partial t}=D_{\text {tobra }} \frac{1}{r^{2}} \frac{\partial}{d r}\left(r^{2} \frac{\partial a}{\partial r}\right)
$$

Eq. 4

with $D_{\text {tobra }}$ taken as the diffusion coefficient for tobramycin in water [16]. Eq. 4 is solved with a time-varying boundary condition, $a=3.3 \mathrm{mg} / \mathrm{L} \exp \left(-0.37 \mathrm{~h}^{-1} t\right)$, from a fit to the measured concentrations in muscle tissue shown in Figure 6. This results in the volume-averaged timeprofiles of concentrations shown in Figure 6. In the figure, the concentration of free tobramycin at the boundary and at the center of the beads are shown with the total concentration at the center. The diffusion-retardation model has been validated over 5 decades of tobramycin concentrations [11] and we expect the predictions to be valid at the same level as the exponential boundary condition (blue dash and data in Figure 6). The calculated, volume averaged, concentration of tobramycin is seen to account for the measured concentration and thereby confirms the quality of the compartment model.

The growth and killing of bacteria are described by the equations;

$$
\frac{\partial \varepsilon}{\partial t}=\mu(c)\left(1-\frac{\varepsilon}{\varepsilon_{\max }}\right) \varepsilon-K_{\max } \frac{\mu(c)}{\mu_{\max }} \frac{a}{K C_{50}+a} \varepsilon
$$




$$
\mu(c)=\mu_{\max } \frac{c}{K_{M}+c}
$$

Eq. 6

Here $K_{\max }$ is the maximum effect of tobramycin, $\mu_{\max }$ is the maximum specific growth rate, and $K C_{50}$ is the half-maimum killing rate concentration of tobramycin. The first term in Eq. 5 describes the bacterial growth and is modelled using Verhulst's logistic model combined with a Monod dependency of oxygen (Eq. 6). The second term in Eq. 5 describes the bacterial death mediated by the tobramycin. This term follows a first order Hill model and the killing is proportional to the bacterial concentration. Adaptation is ignored, hence $K C_{50}$ is constant and set equal to the MIC. In order to ensure an oxygen-dependent killing, the killing term is scaled by the normalized oxygendependent growth $\left(\mu(c) / \mu_{\max }\right)$. In the model, killing is only mediated by tobramycin. Eq. 5 is solved with maximal concentration from the untreated stationary values as measured in our experiment. The volume-averaged concentration of live bacteria is compared to experimentally observed values in Figure 1. In this figure representing the bacterial proliferation and killing by Eq. $5, K_{\max }$ has been adjusted to reproduce the experimentally observed killing while the tobramycin concentration PK was taken from the (decoupled) PK retardation model.

The numerical integration of the equations was performed using the numerical solver by Skeel and colleagues (pdepe in MATLAB version 9.7.0.1190202 (R2019b), Natick, Massachusetts; 2019) [17].

\section{Statistical analysis}

Unpaired t-test were used for analysis of data (Prism, GraphPad Software, San Diego, USA). A pvalue $\leq 0.05$ was considered statistically significant.

\section{Results}

\subsection{Outcome}

All mice survived and revealed no signs of infection during the 24h experiment. The site of installation of $P$. aeruginosa embedded in seaweed alginate did not show any macroscopic signs of inflammation. 


\subsection{Bacterial survival}

The results of the bacterial survival in the retrieved D0 alginate beads are shown as absolute numbers in Figure 1. Since the purpose is to establish a prediction of antibiotic effect in biofilms, besides testing the biofilm pharmacological microcompartment phenomenon in vivo, the data are compared to tobramycin killing model. The data are seen to be in qualitative agreement with our tobramycin killing model for the alginate beads.

In the tobramycin treated group of D0 beads, a statistically significant reduced bacterial survival was observed after $6 \mathrm{~h}(\mathrm{p}<0.0001), 8 \mathrm{~h}$ and $16 \mathrm{~h}(\mathrm{p}<0.0001)$, with an almost 2-log reduction in bacterial levels compared to controls. However, from $16 \mathrm{~h}$ to $24 \mathrm{~h}$, an increase in bacterial numbers was observed. Although the latter increase was not statistically significant $(\mathrm{p}=0.39)$, it revealed that the reduction in numbers of bacteria in the treated group from the starting levels to $24 \mathrm{~h}$ was not statistically significant $(\mathrm{p}=0.20)$.

In the non-treated group, which was added as a background levels, a constant marginal increase in bacterial levels was observed. Compared to the starting concentration at $0 \mathrm{~h}$, bacterial numbers increased after $6 \mathrm{~h}(\mathrm{p}=0.03)$ and $16 \mathrm{~h}(\mathrm{p}=0.03)$, resulting in an approximately $0.5 \log \mathrm{CFU} / \mathrm{mL}$ increase at $24 \mathrm{~h}(\mathrm{p}=0.0006)$. However, the bacterial level in the non-treated group was not significantly different compared to the tobramycin treated D0 group at $24 \mathrm{~h}(\mathrm{p}=0.14)$.

For the D5 alginate beads the bacterial levels were approximately 1-log higher as compared to D0 alginate beads and remained significantly higher including the $16 \mathrm{~h}$ timepoint $(\mathrm{p}<0.003$, Figure 2$)$. However, at 24h there was no longer a statistically significant difference between bacterial levels of D0 and D5 alginate beads.

Comparing the effect of tobramycin on the dynamic of bacterial levels, a significant reduction from $0.5 \mathrm{~h}$ to $6 \mathrm{~h}$ and $16 \mathrm{~h}$ was observed for both D0 and D5 beads (Figure 2). As mentioned above the difference was no longer statistically different for D0 alginate beads at $24 \mathrm{~h}$. However, in the D5 beads the bacterial levels remained statistically lower at $24 \mathrm{~h}$ as compared to $0.5 \mathrm{~h}$.

\subsection{Staining for DNA by propidium iodine}

As tobramycin also can bind to DNA, we exposed the D0 and D5 alginate beads to propidium iodine. In D0 alginate beads few structures compatible with eDNA were revealed. However, for the D5 alginate beads the signal from the beads was too strong to reveal a detailed structure of neither 
the propidium iodine bound to eDNA nor dead bacteria. However, the strong signal supports that tobramycin binding to DNA in alginate beads occurs (Figure 3 ).

\subsection{Tobramycin pharmacokinetic}

Pharmacokinetics data and mean $( \pm \mathrm{SD})$ are presented in Figure 4A and B.

The tobramycin serum concentration peaked at $58.3 \mathrm{mg} / \mathrm{L}( \pm 9.2)$ at $0.5 \mathrm{~h}$ and was reduced to 0.14 $\mathrm{mg} / \mathrm{L}( \pm 0.03)$ after $16 \mathrm{~h}$. Thereafter, the serum concentrations were below the detection level. The concentration in the tissue, represented by the quadriceps muscle, was detectable after $0.5 \mathrm{~h}$ with a mean concentration of $2.8 \mathrm{mg} / \mathrm{L}( \pm 0.5)$ and $0.5 \mathrm{mg} / \mathrm{L}( \pm 0.14)$ after $8 \mathrm{~h}$. At $24 \mathrm{~h}$, the tissue concentration was $0.4 \mathrm{mg} / \mathrm{L}( \pm 0.2)$. For the lungs, the concentrations were $7.1 \mathrm{mg} / \mathrm{L}( \pm 2.3)$ at $0.5 \mathrm{~h}$, $1.3 \mathrm{mg} / \mathrm{L}( \pm 0.2)$ at $3 \mathrm{~h}, 0.5 \mathrm{mg} / \mathrm{L}( \pm 0.2)$ at $6 \mathrm{~h}$, and $0.2 \mathrm{mg} / \mathrm{L}( \pm 0.2)$ at $16 \mathrm{~h}$. After $24 \mathrm{~h}$, lung tobramycin concentrations were still detectable with $0.3 \mathrm{mg} / \mathrm{L}( \pm 1.1)$.

For the D0 alginate, a tobramycin mean concentration of $10.9 \mathrm{mg} / \mathrm{L}( \pm 1.6)$ was measured after $0.5 \mathrm{~h}$, increasing to $19.8 \mathrm{mg} / \mathrm{L}( \pm 3.5)$ at $3 \mathrm{~h}$, with a subsequent slow elimination to $10 \mathrm{mg} / \mathrm{L}( \pm 1.7)$ and 9 $\mathrm{mg} / \mathrm{L}( \pm 3.2)$ at $6 \mathrm{~h}$ and $8 \mathrm{~h}$, respectively. After 16 hours, the concentration further declined to 0.2 $\mathrm{mg} / \mathrm{L}( \pm 0.1)$ and tobramycin levels were undetectable after $16 \mathrm{~h}$.

For the D5 alginate, the mean tobramycin concentration after $0.5 \mathrm{~h}$ was $14.7( \pm 3.8)$ and increased to $24.8 \mathrm{mg} / \mathrm{L}( \pm 4.1)$ at $3 \mathrm{~h}$. Afterwards concentrations decreased to $16.7 \mathrm{mg} / \mathrm{L}( \pm 1.8)$ at $6 \mathrm{~h}, 6.6( \pm 1.2)$ at $16 \mathrm{~h}$ and $0.7 \mathrm{mg} / \mathrm{L}( \pm 0.7)$ at $24 \mathrm{~h}$.

\subsection{PK biofilm calculations}

In order to get a rough estimate of the tobramycin concentration cross section in the alginate beads, we used the previously described phenomenological diffusion retardation model [10]. In Figure 5, we show the resulting volume averaged total concentration which is seen to be in qualitative agreement with the observed concentration. The total concentration at the center and the free concentration is also shown. With beads of diameter as large as $2.3 \mathrm{~mm}$, i.e. significantly larger than typical alginate structures in biofilms, we observe that the concentration starts to build up only after about 3 hours and that the free concentration remains lower than the MIC. 
P. aeruginosa cultured at each time point did not show increased MICs for tobramycin (planktonic growth), and tobramycin resistance (in vivo and in vitro resistance) was not revealed during the short treatment period.

\section{Discussion}

Handling of bacterial biofilm infections is considered one of the modern medical world's big challenges [3]. Despite increasing understanding and improved handling, major challenges remain since biofilm infections often cannot be cured, once established.

Investigating the hypothesis of considering biofilms as an independent PK microcompartment, needed a novel model to be able to perform simultaneous PK/PD measurements, since this was not possible in existing models. Therefore, we established the in vitro model modifying our already present use of seaweed alginate beads and confirmed the hypothesis, at least for tobramycin [10]. In that study, we confirmed the reduced bacterial killing of tobramycin monotherapy of biofilm growing as compared to planktonic growing $P$. aeruginosa. This proof-of-concept has been used as a model system, even though combination antibiotic therapy would probably improve the effect. Furthermore, we provided calculations on the diffusion of tobramycin in the model system and revealed that the phenomenon contributes substantially to the tobramycin tolerance observed in $P$. aeruginosa biofilm infections [11]. The present study aimed at testing the phenomenon in vivo in a modified animal wound model where host factors could potentially augment the bacterial clearing.

Compared to the in vitro study where a 1-log bacterial killing was observed, the present study confirmed this tobramycin effect, although with substantial variations with an approximately 1-log in vivo killing effect of D0 and D5 biofilms observed after $8 \mathrm{~h}$. However, also the contributing innate host response can potentially explain a minor part of the killing [18]. Therefore, the present study did confirm an only modest killing of bacteria in the alginate beads, despite a tobramycin accumulation of 6-7 times or more above the surrounding concentrations. This observation was even more pronounced for the D5 biofilms where tobramycin concentrations were significantly higher at $6 \mathrm{~h}$ and $16 \mathrm{~h}$ after treatment as compared to the D0 biofilms. The relatively less pronounced killing in D5 beads in connection to increased tobramycin concentrations in the beads may reflect a substantially higher amount of eDNA in the older beads. This was made probable by means of exposing the D0 and D5 beads to propidium iodine which binds to DNA. In the D0 beads, elements likely representing eDNA were observed. However, for the D5 beads, no structures were clearly 
revealed due to the extent of staining by propidium iodine and the resulting strong signal. Besides substantial amounts of eDNA this may also represent a higher number of dead bacteria, although the present methodology used in this study did not allow for such distinction. In addition, the presumably more metabolically active bacteria in the D0 beads may be more prone to tobramycin effect as compared to less metabolically active cells in the older and more mature biofilm formation in D5 beads.

In addition, the present study confirmed the slowly release of tobramycin from the alginate, resulting in a tobramycin concentration significantly above the MIC for at least $8 \mathrm{~h}$. However, with the limited free concentration of tobramycin the bacterial killing is modest, probably because optimal tobramycin effect is dose dependent and the alginate binding hampers this effect [11]. The lack of satisfying effect is also in accordance with previous results from our group, showing that it is only the metabolic active and aerobic surface of the biofilm which is killed by tobramycin [19] and is also in accordance with our published clinical results from CF patients [20]. Consequently, the alginate cannot be considered as an antibiotic reservoir that improves the bacterial killing. In contrast, the results of the present study suggest that the accumulated tobramycin with the low free concentration and the prolonged exposure may instead increase the risk of inducing mutational bacterial resistance to tobramycin although it requires longer exposure to the drug [17] as has been shown in clinical trials [22]. This suggested "hot spot" for developing tobramycin resistance can potentially be investigated with the present model, although not the focus for this study. Another interesting observation was the fast regrowth of $P$. aeruginosa at termination of the study for the D0 biofilms. However, for the D5 biofilms where the number of bacteria was 10x higher when installed in the animals, a regrowth was not observed. This could be explained by the presumed slower growth of bacteria in the older biofilm or the more pronounced accumulation of tobramycin in the older biofilm. However, the exact explanation cannot be determined by the present study design. The regrowth in the D0 biofilms was observed despite the host defense, and only after elimination of the tobramycin. In addition, the regrowth was not a result of developed tobramycin resistance, simply as a consequence of the well described biofilm tolerance [21]. The observation underlines the significance of avoiding too long antibiotic free intervals and supports the importance of combining antibiotic classes with different antibacterial killing mechanisms and different PKs to better reduce the antibiotic free intervals $[7,19]$. This observation is also supported by a recent in vitro study, showing regrowth of biofilm growing $P$. aeruginosa by means of confocal microscopy, when dosing intervals were too long [23]. The present study did not evaluate 
the degree of host response and with the relative sparsely early clinical signs of an inflammatory response, the host contribution to the bacterial killing was probably limited.

The current observation that $P$. aeruginosa in the biofilm infections is actually impacted by the exposure to antibiotics is supported by a recent study [20]. The investigation of paired sputum samples before and after relevant antibiotic therapy for chronic $P$. aeruginosa lung infections, revealed reduced bacterial loads after the treatment, but also increased antibiotic resistance [20]. Interestingly, the biofilms seemed to change their appearance looking more condensed after treatment [20]. Previously, we tested tobramycin dosing against three clinical mucoid isotype isolates using our seaweed alginate lung model. In accordance with the clinical observations and our present study, a one dose of tobramycin was not able to clear the lung infection even though the tobramycin dosage used was $3 x$ higher in that previous study than the dosage used in our present study. This lack of effect was even more pronounced if treatment was delayed for $24 \mathrm{~h}$ [24]. For one isolate even repeated treatment for three days did not clear the infection [24].

Poor penetration of antibiotics into biofilms was repeatedly suggested to be the reason for the poor antibiotic effect against biofilm infections [21]. However, penetration of fluoroquinolones, piperacillin, vancomycin and daptomycin, was not limited by the nature of biofilms, in accordance with our observations [25-27]. This also suggests for investigating additional antibiotics PK/PD in our model system.

Our study has some limitations. Firstly, in order to investigate $P$. aeruginosa biofilms, especially in a CF context, an in vivo lung model would be preferable. However, using our lung seaweed alginate infection model we previously observed a similar lack of tobramycin killing effect, even though tobramycin dosages were $3 x$ higher [24], Nevertheless, we cannot determine the simultaneous tobramycin biofilm concentration using that model, because the required bead size for a lung infection is too small to recover for PK determination. Since mucus has been shown to further challenge the tobramycin effect in an in vitro set up a direct pulmonary evaluation would be intriguing [28]. However, such an animal model enabling us to perform PK and PD parameter calculations simultaneously, does not exist at present. Even though the tobramycin concentration in the lung tissue after $0.5 \mathrm{~h}$ was significantly higher compared to the adjacent muscle tissue, the tobramycin lung concentrations in the rest of the measured dosing interval were not significantly different from the observed penetration to the muscle tissue in our study. Secondly, the size of the beads is much larger than the reported in vivo biofilm sizes [29]. However, the sizes were chosen to 
be able to compare the present results with our previous in vitro observations and to be able to detect the beads inside the mice and to obtain sufficient tobramycin concentrations which could be used for calculations. In the present study, total tobramycin concentrations were measured and used for modeling and interpretation. This approach can be justified due to the neglectable tobramycin protein binding. Finally, the concept of the present modification of the alginate bead model $[10,11,13]$ for in vitro studies, has inspired fellow researchers to replicate the model for other investigative studies of biofilms [30,31], supporting the advantages of the model. The results of the present study are in accordance with the idea that in vivo biofilms should be regarded as independent pharmacological microcompartments. Importantly, the tobramycin killing effect within the biofilm was arrested after $8 \mathrm{~h}$ even though the total tobramycin concentration remained above the MIC $(1.5 \mathrm{mg} / \mathrm{L})$. In the young D0 biofilms this even resulted in a regrowth of the bacteria. The study supports the need for investigating biofilm PKs with other antibiotics and indicates the importance of finding new treatment strategies reducing the $P$. aeruginosa biofilm matrix to obtain improved therapeutic efficacy in CF patients $[32,33]$.

\section{Acknowledgements}

Funding: This work was supported by the Novo Nordisk Foundation - "Borregaard Clinical Scientist Grant" (grant NNF17OC0025074); the Danish Cystic Fibrosis Association (Introduction research grant).

\section{Authorship}

Claus Moser and Lars Christophersen made the conception and design of the study. All authors have made substantial contributions to the acquisition of data, analysis and interpretation of data, (2) revising the manuscript critically and (3) approved the final version to be submitted.

\section{Conflicts of interest statement}

The authors declare no conflict of interest. 


\section{References}

[1] Skov M, Hansen CR, Pressler T. Cystic fibrosis - an example of personalized and precision medicine. Apmis 2019;127:352-60. https://doi.org/10.1111/apm.12915.

[2] Høiby N, Bjarnsholt T, Moser C, Jensen PØ, Kolpen M, Qvist T, et al. Diagnosis of biofilm infections in cystic fibrosis patients. APMIS 2017;125:339-43. https://doi.org/10.1111/apm.12689.

[3] Høiby N, Bjarnsholt T, Moser C, Bassi GLL, Coenye T, Donelli G, et al. ESCMID guideline for the diagnosis and treatment of biofilm infections 2014. Clin Microbiol Infect 2015;21:S1-25. https://doi.org/10.1016/j.cmi.2014.10.024.

[4] Høiby N, Bjarnsholt T, Givskov M, Molin S, Ciofu O. Antibiotic resistance of bacterial biofilms. Int J Antimicrob Agents 2010;35:322-32. https://doi.org/10.1016/j.ijantimicag.2009.12.011.

[5] Kragh KN, Alhede M, Jensen PØ, Moser C, Scheike T, Jacobsen CS, et al. Polymorphonuclear leukocytes restrict growth of Pseudomonas aeruginosa in the lungs of cystic fibrosis patients. Infect Immun 2014;82:4477-86. https://doi.org/10.1128/IAI.0196914.

[6] Chiang WC, Nilsson M, Jensen PØ, Høiby N, Nielsen TE, Givskov M, et al. Extracellular DNA shields against aminoglycosides in Pseudomonas aeruginosa biofilms. Antimicrob Agents Chemother 2013;57:2352-61. https://doi.org/10.1128/AAC.00001-13.

[7] Pamp SJ, Gjermansen M, Johansen HK, Tolker-Nielsen T. Tolerance to the antimicrobial peptide colistin in Pseudomonas aeruginosa biofilms is linked to metabolically active cells, and depends on the pmr and mexAB-oprM genes. Mol Microbiol 2008. https://doi.org/10.1111/j.1365-2958.2008.06152.x.

[8] Bagge N, Schuster M, Hentzer M, Ciofu O, Givskov M, Greenberg EP, et al. Pseudomonas aeruginosa Biofilms Exposed to Imipenem Exhibit Changes in Global Gene Expression and $\beta$-Lactamase and Alginate Production. Antimicrob Agents Chemother 2004. https://doi.org/10.1128/AAC.48.4.1175-1187.2004.

[9] Zimmerli W, Moser C. Pathogenesis and treatment concepts of orthopaedic biofilm 
infections. FEMS Immunol Med Microbiol 2012;65:158-68. https://doi.org/10.1111/j.1574695X.2012.00938.x.

[10] Cao B, Christophersen L, Thomsen K, Sønderholm M, Bjarnsholt T, Jensen PØ, et al. Antibiotic penetration and bacterial killing in a Pseudomonas aeruginosa biofilm model. $\mathbf{J}$ Antimicrob Chemother 2015;70:2057-63. https://doi.org/10.1093/jac/dkv058.

[11] Cao B, Christophersen L, Kolpen M, Jensen PØ, Sneppen K, Høiby N, et al. Diffusion Retardation by Binding of Tobramycin in an Alginate Biofilm Model. PLoS One 2016;11:e0153616. https://doi.org/10.1371/journal.pone.0153616.

[12] Pedersen SS, Shand GH, Hansen BL, Hansen GN. Induction of experimental chronic Pseudomonas aeruginosa lung infection with $P$. aeruginosa entrapped in alginate microspheres. APMIS 1990. https://doi.org/10.1111/j.1699-0463.1990.tb01023.x.

[13] Christophersen LJ, Trøstrup H, Malling Damlund DS, Bjarnsholt T, Thomsen K, Jensen PØ, et al. Bead-size directed distribution of Pseudomonas aeruginosa results in distinct inflammatory response in a mouse model of chronic lung infection. Clin Exp Immunol 2012;170:222-30. https://doi.org/10.1111/j.1365-2249.2012.04652.x.

[14] Gade PAV, Olsen TB, Jensen PØ, Kolpen M, Høiby N, Henneberg KA, et al. Modelling of ciprofloxacin killing enhanced by hyperbaric oxygen treatment in Pseudomonas aeruginosa PAO1 biofilms. PLoS One 2018;13:1-16. https://doi.org/10.1371/journal.pone.0198909.

[15] Hall JE. Guyton and Hall Textbook of Medical Physiology. Elsevier 1946;13th editi.

[16] Nichols WW, Dorrington SM, Slack MPE, Walmsley HL. Inhibition of Tobramycin Diffusion by Binding to Alginate. Antimicrob Agents Chemother 1988;32:518-23. https://doi.org/https://doi.org/10.1128/AAC.32.4.518.

[17] Skeel RD, Berzins M. A Method for the Spatial Discretization of Parabolic Equations in One Space Variable. SIAM J Sci Stat Comput 1990. https://doi.org/10.1137/0911001.

[18] Moser C, Pedersen HT, Lerche CJ, Kolpen M, Line L, Thomsen K, et al. Biofilms and host response - helpful or harmful. APMIS 2017;125:320-38. https://doi.org/10.1111/apm.12674.

[19] Herrmann G, Yang L, Wu H, Song Z, Wang H, Høiby N, et al. Colistin-tobramycin 
combinations are superior to monotherapy concerning the killing of biofilm Pseudomonas aeruginosa. J Infect Dis 2010;202:1585-92. https://doi.org/10.1086/656788.

[20] Fernández-Barat L, Ciofu O, Kragh KN, Pressler T, Johansen U, Motos A, et al. Phenotypic shift in Pseudomonas aeruginosa populations from cystic fibrosis lungs after 2-week antipseudomonal treatment. J Cyst Fibros 2017;16:222-9. https://doi.org/10.1016/j.jcf.2016.08.005.

[21] Ciofu O, Rojo-Molinero E, Macià MD, Oliver A. Antibiotic treatment of biofilm infections. APMIS 2017;125:304-19. https://doi.org/10.1111/apm.12673.

[22] Burns JL, Van Dalfsen JM, Shawar RM, Otto KL, Garber RL, Quan JM, et al. Intermittent administration of inhaled tobramycin in patients with cystic fibrosis. J Infect Dis 1999;179:1190-7. https://doi.org/10.1056/NEJM199901073400104.

[23] Müsken M, Pawar V, Schwebs T, Bähre H, Felgner S, Weiss S, et al. Breaking the Vicious Cycle of Antibiotic Killing and Regrowth of Biofilm-Residing Pseudomonas aeruginosa. Antimicrob Agents Chemother 2018;62. https://doi.org/10.1128/AAC.01635-18.

[24] van Gennip M, Moser C, Christensen LD, Bjarnsholt T, Calum H, Jensen P, et al. Augmented effect of early antibiotic treatment in mice with experimental lung infections due to sequentially adapted mucoid strains of Pseudomonas aeruginosa. J Antimicrob Chemother 2009;64:1241-50. https://doi.org/10.1093/jac/dkp352.

[25] Stewart PS. Mechanisms of antibiotic resistance in bacterial biofilms. Int J Med Microbiol 2002;292:107-13. https://doi.org/10.1078/1438-4221-00196.

[26] Suci PA, Mittelman MW, Yu FP, Geesey GG. Investigation of ciprofloxacin penetration into Pseudomonas aeruginosa biofilms. Antimicrob Agents Chemother 1994;38:2125-33. https://doi.org/https://doi.org/10.1128/aac.38.9.2125.

[27] Stewart PS, Davison WM, Steenbergen JN. Daptomycin rapidly penetrates a Staphylococcus epidermidis biofilm. Antimicrob Agents Chemother 2009;53:3505-7. https://doi.org/10.1128/AAC.01728-08.

[28] Müller L, Murgia X, Siebenbürger L, Börger C, Schwarzkopf K, Sewald K, et al. Human airway mucus alters susceptibility of Pseudomonas aeruginosa biofilms to tobramycin, but 
[29] Bjarnsholt T, Alhede MM, Alhede MM, Eickhardt-Sørensen SR, Moser C, Kühl M, et al. The in vivo biofilm. Trends Microbiol 2013;21:466-74. https://doi.org/10.1016/j.tim.2013.06.002.

[30] Sønderholm M, Kragh KN, Koren K, Jakobsen TH, Darch S, Alhede M, et al. Aggregate formation of Pseudomonas aeruginosa in an alginate bead model system exhibits in vivo like characteristics. Appl Environ Microbiol 2017:AEM.00113-17. https://doi.org/10.1128/AEM.00113-17.

[31] Sønderholm M, Koren K, Wangpraseurt D, Jensen PØ, Kolpen M, Kragh KN, et al. Tools for studying growth patterns and chemical dynamics of aggregated Pseudomonas aeruginosa exposed to different electron acceptors in an alginate bead model. Npj Biofilms Microbiomes 2018. https://doi.org/10.1038/s41522-018-0047-4.

[32] Hengzhuang W, Song Z, Ciofu O, Onsøyen E, Rye PD, Høiby N. OligoG CF-5/20 Disruption of Mucoid Pseudomonas aeruginosa Biofilm in a Murine Lung Infection Model. Antimicrob Agents Chemother 2016;60:2620-6. https://doi.org/10.1128/AAC.01721-15.

[33] Tavafi H, Ali AA, Ghadam P, Gharavi S. Screening, cloning and expression of a novel alginate lyase gene from P. aeruginosa TAG 48 and its antibiofilm effects on P. aeruginosa biofilm. Microb Pathog 2018;124:356-64. https://doi.org/10.1016/j.micpath.2018.08.018.

[34] Heilesen AM, Permin H, Koch C, Høiby N. Treatment of Chronic Pseudomonas aeruginosa Infection in Cystic Fibrosis Patients with Ceftazidime and Tobramycin. Scand J Infect Dis 1983;13:271-6. https://doi.org/https://doi.org/10.3109/inf.1983.15.issue-3.07.

[35] Arai H, Kawakami T, Osamura T, Hirai T, Sakai Y, Ishii M. Enzymatic characterization and in vivo function of five terminal oxidases in Pseudomonas aeruginosa. J Bacteriol 2014;196:4206-15. https://doi.org/10.1128/JB.02176-14.

[36] Han P, Bartels DM. Temperature Dependence of Oxygen Diffusion in H2O and D2O. J Phys Chem 1996;100. https://doi.org/https://doi.org/10.1021/jp952903y. 


\section{Legends to Figures}

Figure 1. Quantitative bacteriology. Quantitative bacteriology inside the D0 alginate beads recovered at different time points after s.c. installation in mice. The time points also represent the time from administration of tobramycin $40 \mathrm{mg} / \mathrm{kg}$ s.c. The $\mathrm{y}$-axis is a logarithmic scale. Non-treated mice (controls) are represented by red points and line and tobramycin treated mice represented by blue squares and line. Each point represents the mean bacterial count in all mice sacrificed at that point in time. The error bars represent SEM. The lines represent the killing model prediction of the bacterial concentration at the given point in time.

Figure 2. Antibiotic effect on D0 and D5 beads. Quantitative bacteriology at different timepoints for D0 (solid circles) and D5 (open circles) during a 24h tobramycin treatment experiment comparing the starting point with the different timepoints. Besides individual measurements the mean and +/- SEM is indicated. Bars with asterisk represents significant difference in quantitative bacteriology compared to the $0.5 \mathrm{~h}$ timepoint. In addition, a significant higher quantitative bacteriology was observed in D5 beads as compared to D0 beads, except at $24 \mathrm{~h}$.

Figure 3. eDNA. Confocal laser scanning microscopy of D0 and D5 beads containing $P$. aeruginosa and exposed to propidium iodine. A represents D0 beads, and B is a 630X magnification. The arrows point's at structures believed to represent eDNA. C represents D5 beads and no clear structures, including eDNA can be identified due to the strong signal.

Figure 4. Biofilm tobramycin concentrations. Mean of measured tobramycin concentrations in serum, lungs and in the muscle tissue closest to the alginate beads (A), and in the D0 and D5 alginate beads (B). The $\mathrm{x}$-axis represents the time after the s.c. installation of beads in the mice and 
the time from administration of tobramycin $40 \mathrm{mg} / \mathrm{kg}$ s.c. Error bars represents SEM. Asterisk indicates $\mathrm{p} \leq 0.05$ between the D0 and the D5 beads.

Figure 5. Modelled tobramycin biofilm concentrations. The modeled total volume averaged concentration of tobramycin in the alginate beads (full line) compared to the mean experimental data (black dots +/- SEM). Also, the calculated total concentration at the center of the beads (dashed line) and the calculated free concentration at the center of the beads (dash-dot) are shown. Finally, the free concentration at the surface (dotted) representing the exponential boundary condition tissue-alginate interface is shown. The exponential (dotted line) is a fit to the measured concentrations in the tissue surrounding the beads (blue data points). The predictions are based on the diffusion retardation model which was validated in vitro over 5 decades of tobramycin concentration [11]. Therefore, the predictions are expected to be valid at the same level as the data and exponential fit to the tobramycin concentration in the surrounding tissue (blue data and dotted line). The comparison between model and measurement of the total tobramycin confirms this qualitatively.

TABLE

\begin{tabular}{|c|l|l|}
\hline Symbol value, unit & Description & Reference \\
\hline$\alpha=16 \frac{\mathrm{mg}}{\mathrm{L}}$ & Constant related to tobramycin binding by the alginate & {$[10]$} \\
\hline$\beta=0.76$ & Power related to tobramycin binding by the alginate & {$[10]$} \\
\hline
\end{tabular}




\begin{tabular}{|c|l|l|}
\hline$D_{\text {tobra }}=1.4 \frac{\mathrm{mm}^{2}}{\mathrm{~h}}$ & Tobramycin diffusion constant & {$[16]$} \\
\hline tobra $a_{\max }=3.3 \mathrm{mg} / \mathrm{L}$ & Maximal tobramycin concentration in muscle tissue & Current \\
\hline tobra ${ }_{\text {rate }}=0.37 \mathrm{~h}^{-1}$ & Elimination rate of tobramycin in muscle tissue & Current \\
\hline$K_{\max }=4.5 \mathrm{~h}^{-1}$ & Maximum effect of tobramycin & Current \\
\hline$K C_{50}=1.5 \mathrm{mg} / \mathrm{L}$ & Half maximal killing concentration (set to MIC). & {$[34]$,} \\
current
\end{tabular}

Table 1. Parameters used in the tobramycin killing model. 
Figure 1. (single column)

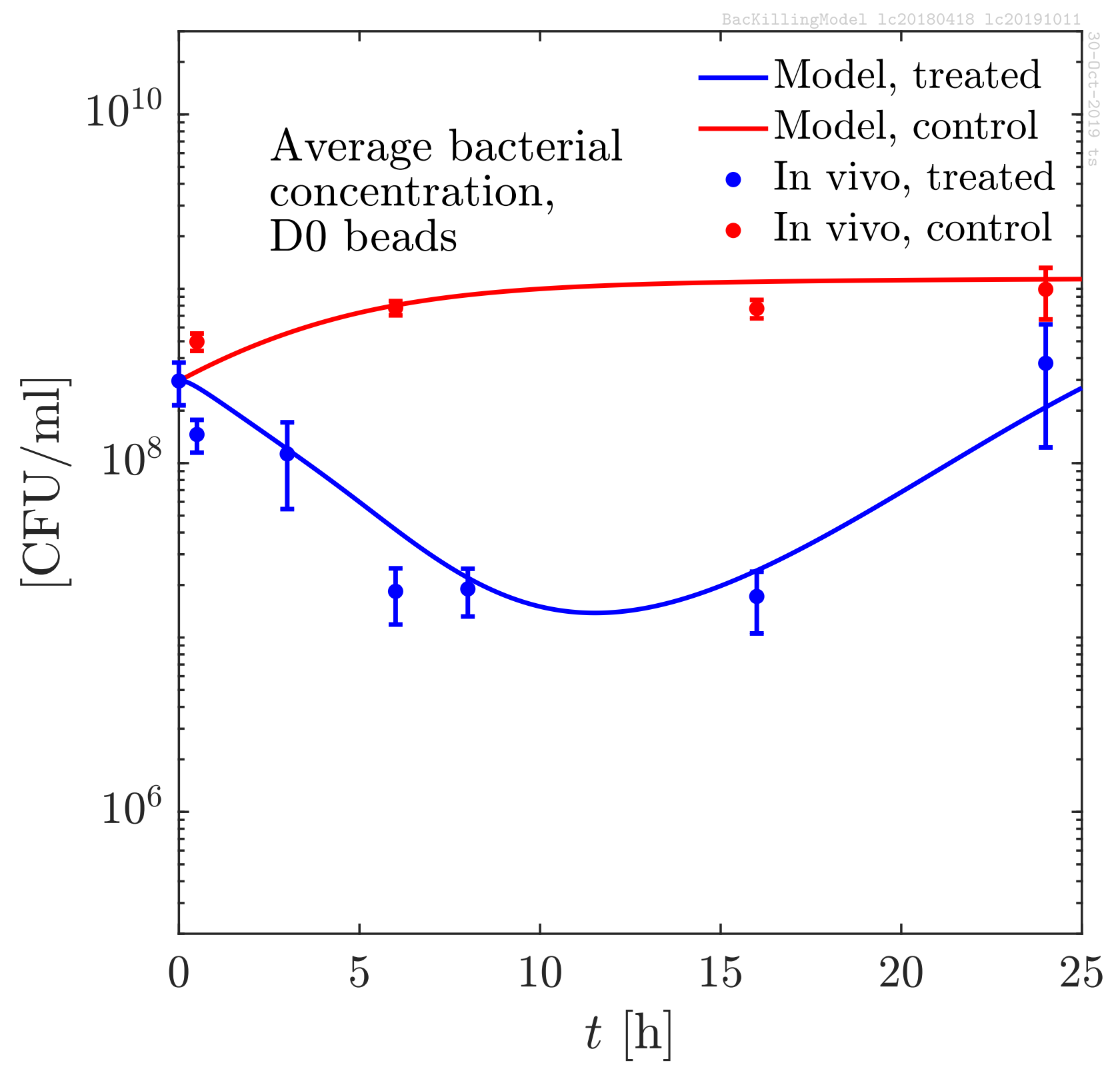


Figure 2. (1.5 column)

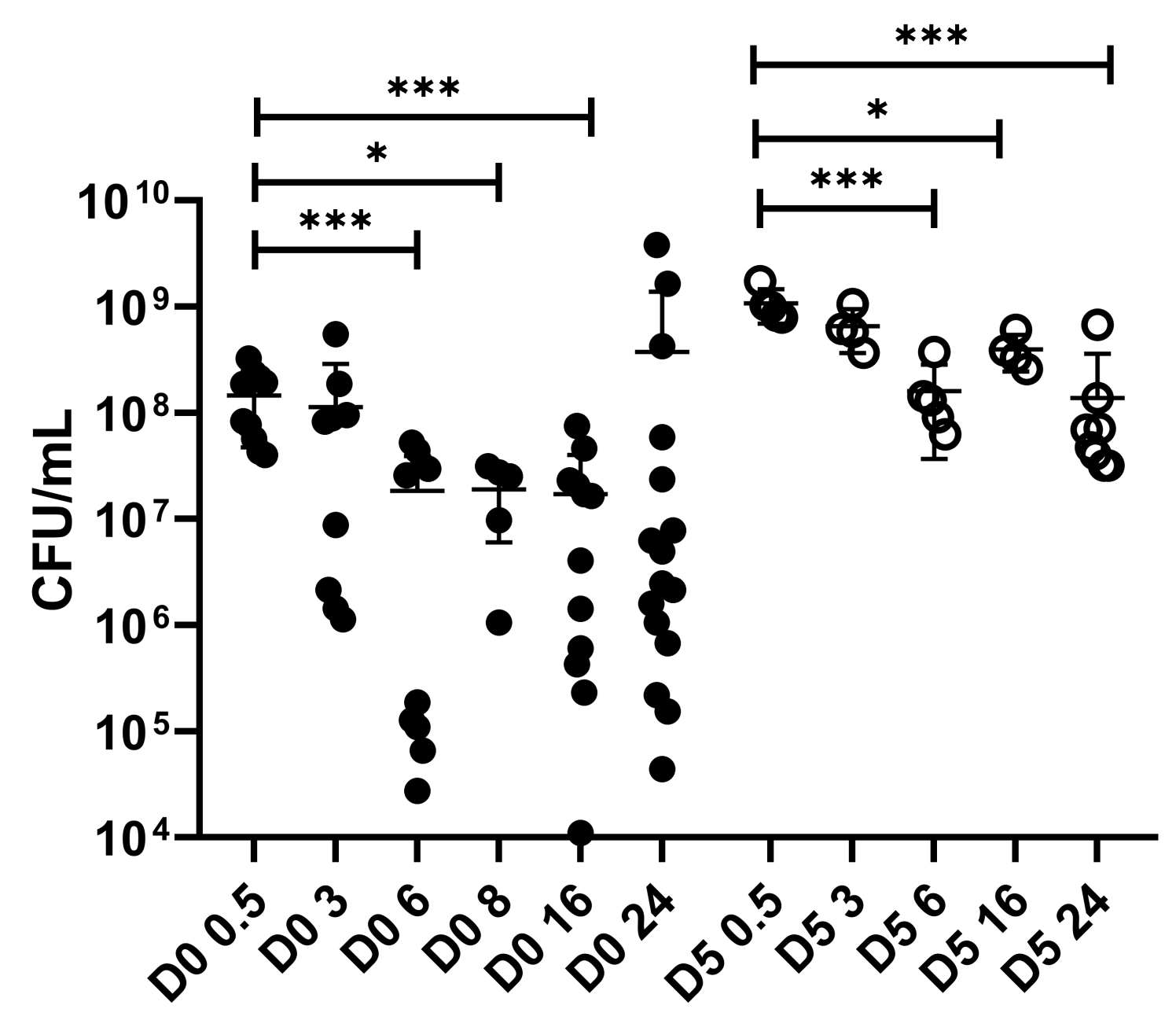


Figure 3. (2 columns)

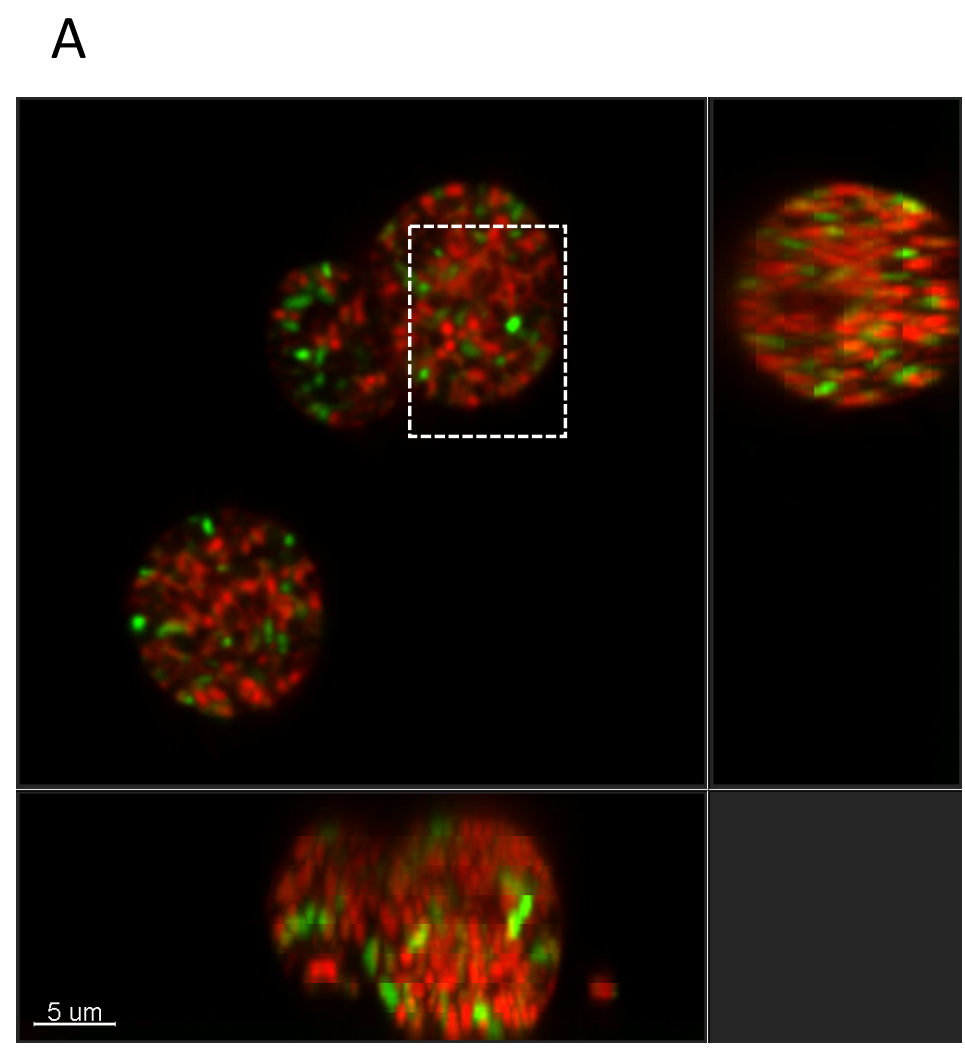

B
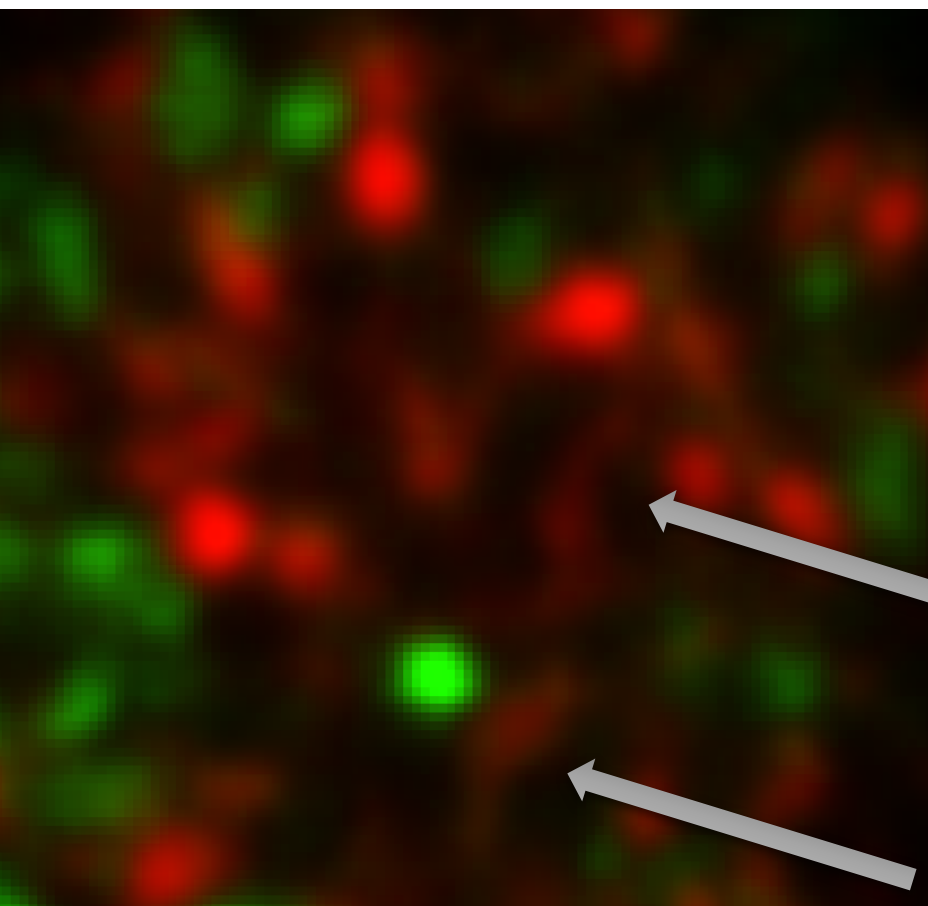

C

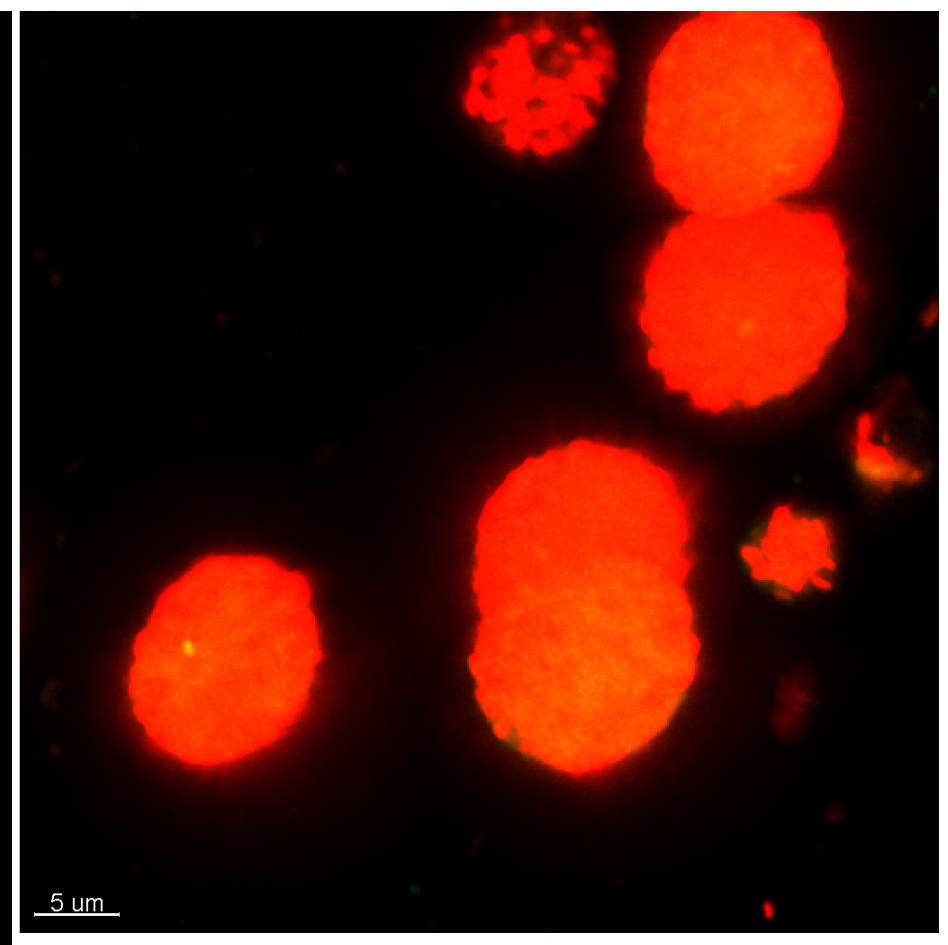


Figure 4. ( 2 columns)

A

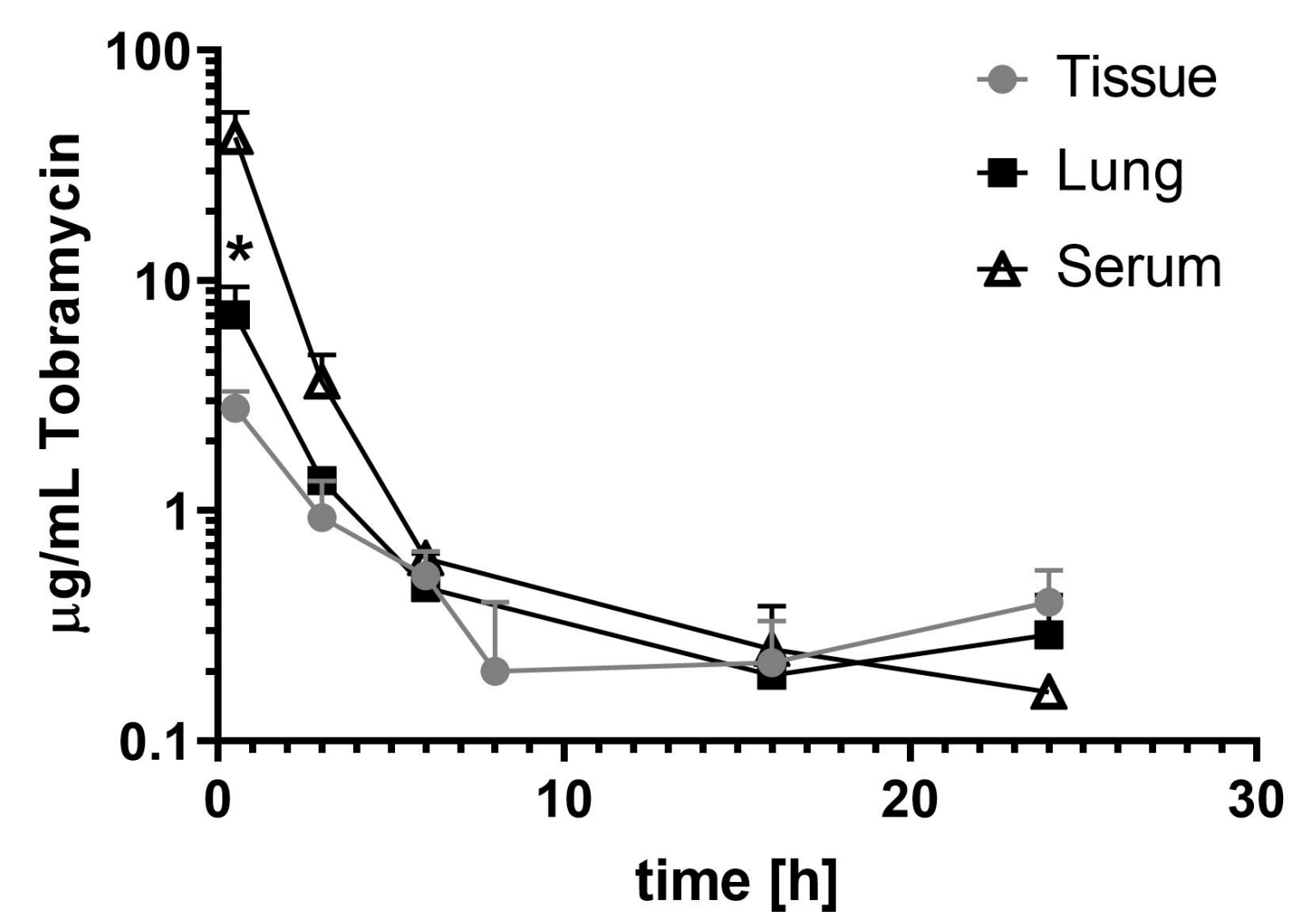

B

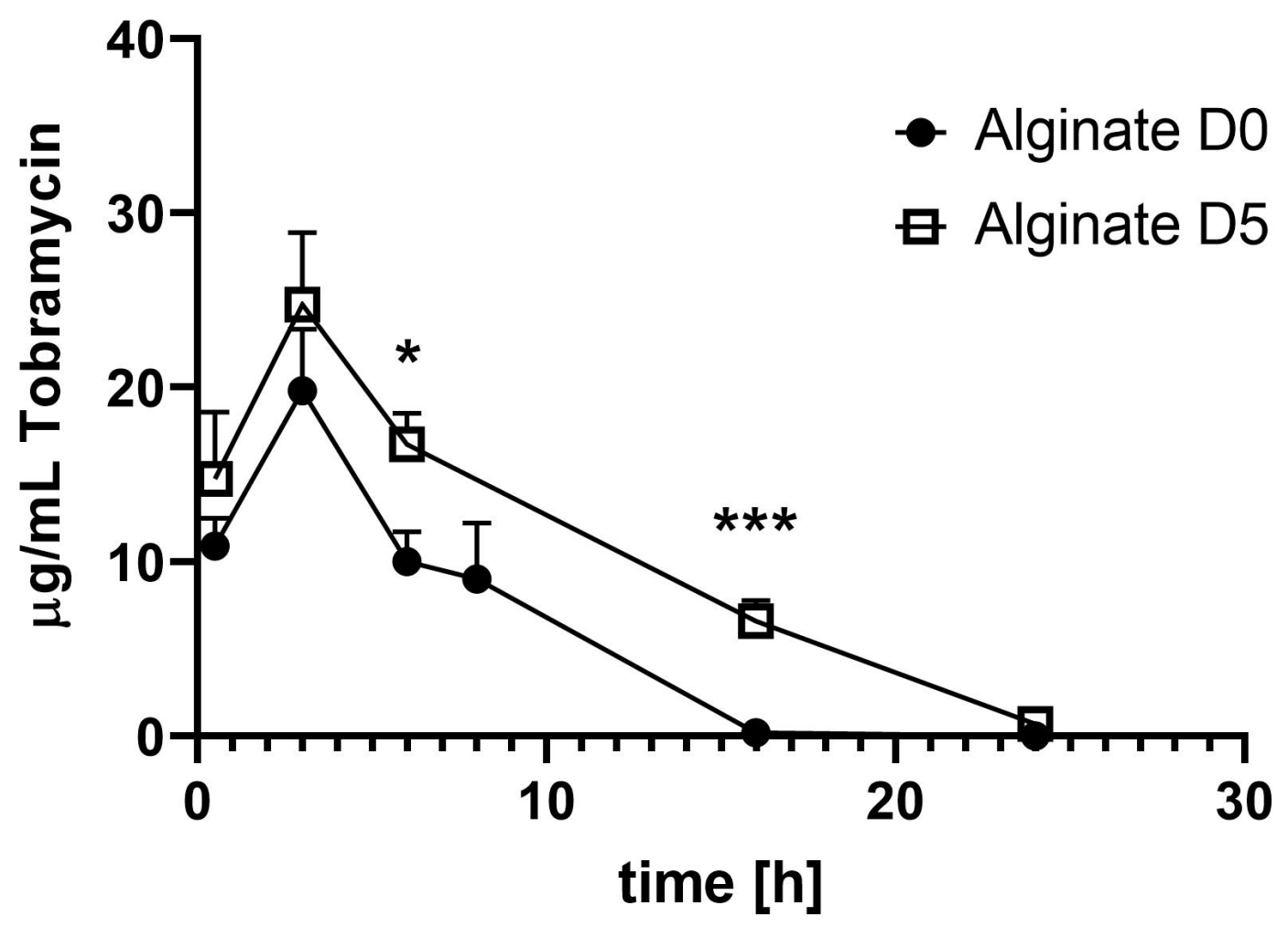


Figure 5. (1.5 columns)

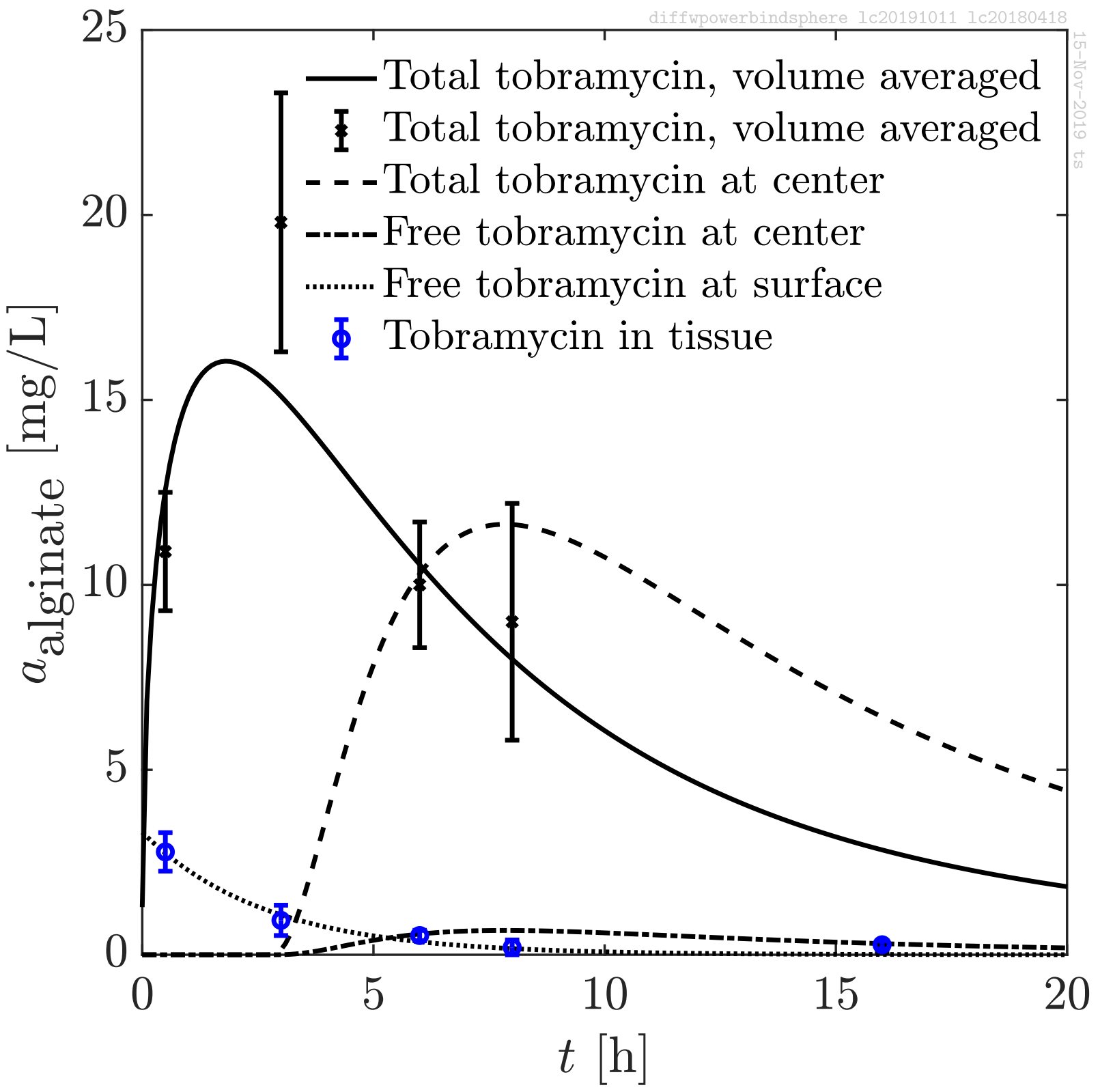

